\section{BDA BULLETIN}

- The BDA has welcomed significant changes to the requirements set out in the English Department of Health's decontamination guidance document HTM 01-05. The most significant change is the extension to the shelf life of wrapped instruments from 21 or 60 days to a maximum of one year. The policy on manually cleaning and rinsing instruments has also been amended. The use of one sink and a removable bowl is now permitted. Manual washing and rinsing can now be achieved by using either two dedicated sinks with a separate or shared water supply, or one sink with a removable bowl that can be contained within the sink and can accommodate the instruments for rinsing. www.gov.uk/government/ publications/decontamination-inprimary-care-dental-practices
- The BDA has issued a fresh call for illegal tooth whitening by nondental professionals to be stamped out, and urges dental professionals to play their part in forcing the demise of the 'whitening cowboys' You can help ensure patients are aware of the risks involved in illegal whitening by displaying one of the BDA's '7 things you didn't know about tooth whitening' posters in your waiting area.

- The BDA has welcomed the announcement that NHS England is to look closely at how dental services can be improved for vulnerable patients and individuals who are not accessing care.

- The BDA has launched a survey of final year dental students to examine the impact of studyrelated debt on access to the profession and career plans. Recent research by the BDA indicates that the impact of increased tuition fees could act as a deterrent for some students.

\title{
COULD CHOCOLATE REPLACE TOOTHPASTE?
}

An organic compound, theobromine, found in chocolate is better than fluoride at remineralising and hardening tooth enamel, according to a new study published in Caries Research. ${ }^{1}$

The study investigated the surface micro-hardness of enamel after artificial enamel lesions were treated with theobromine, fluoride or artificial saliva. While artificial saliva did not contribute to enamel remineralisa-

tion, theobromine demonstrated mineral gain at a greater rate than fluoride. By increasing the size of apatite crystals that form and strengthen enamel, theobromine makes teeth less vulnerable to bacterial acid erosion that can eventually lead to cavities.

Theobromine is an active ingredient in Rennou, the patented chocolate extract used in Theodent toothpastes (available in the US and Canada), which is safe to swallow. Rennou was invented by a dentist with a $\mathrm{PhD}$ in nutrition who spent his professional career studying the effects of methylated xanthines on teeth. He collaborated with two experts in analytical geology and discovered Rennou's effects on teeth and enamel.

With this study supporting the efficacy of theobromine, the chocolate extract could set the stage for other alternatives to fluoridebased oral care products.

1. Amaechi B T, Porteous N, Ramalingam K et al. Remineralization of artificial ename lesions by theobromine. Caries Res 2013; 47: 399-405.

\section{HONOURS, AWARDS, APPOINTMENTS}

Undisputed lingual leader

Orthodontist Didier Fillion, 'the orthodontist who has done more than anyone else to further the cause of lingual systems', was celebrated by the British Lingual Orthodontic Society (BLOS) at its spring meeting and presented with Life Membership. Dr Fillion learned about the lingual technique directly from its inventors in the 1980s and has inspired a practice dedicated to lingual ever since, teaching and inspiring younger practitioners as new and more sophisticated lingual systems were brought to market.

Chair of Alpha Omega London

Specialist prosthodontist Harris Sidelsky is to succeed Linda Greenwall as Chairperson of the Alpha Omega London Chapter in September. Alpha Omega is a worldwide dental organisation dedicated to battling inequality and promoting excellence in all areas of dentistry.

Benevolent Fund Manager

The BDA Benevolent Fund has appointed Ms Liz Rickarby as General Manager. Ms Rickarby takes over from Mrs Sally Atkinson who served 16 years in the role before starting her retirement in this month.

\section{Most Outstanding Contribution}

Dr Mervyn Druian was the recipient of the Outstanding Contribution to Aesthetic Dentistry 2013 Award at the Aesthetic Dentistry Awards. Dr Druian has been in the dental industry for over 30 years and is well known for his ground-breaking treatments and techniques.

\section{Policy and Professional Services}

Martin Woodrow has been appointed as the new Director of Policy and Professional Services for the BDA. He will take up the post in August this year, taking over from Linda Wallace. Mr Woodrow is currently National Secretary for the British Medical Association in Scotland.

\section{Best British dentist}

Periodontist Peter Galgut, who practises in Golders Green, has been elected UK National Dentist of the Year 2013 by the British Dental Health Foundation, having first been given the accolade in 2010. The award is in acknowledgement of Dr Galgut's ongoing commitment to continuing education, postgraduate education and dissemination of preventive care information to the public, and for his charitable work.

\section{Advert awards}

The British Dental Trade Association's 2013 campaign promoting BDTA Dental Showcase has been voted winner in the 'highest information value' category, joint second in the 'highest believability' category and third overall in the 'highest attention-getting ability' category, following a research project into $B D J$ readers' responses to adverts carried out by Readex Research. Colgate (Duraphat) came first in believability and Oral B Seminars came joint second. Wrigley's (Extra) came highest in attention-getting ability with Colgate (Duraphat) in second place. 